\title{
Maastrichtian island in the central European Basin-new data inferred from palynofacies analysis and inoceramid stratigraphy
}

\author{
Agata Jurkowska $^{1} \cdot$ Marcin Barski $^{2}$
}

Received: 28 February 2017 / Accepted: 11 August 2017 / Published online: 1 September 2017

(C) The Author(s) 2017. This article is an open access publication

\begin{abstract}
The palynological study and palynofacies analysis supported by size analysis of opaque phytoclasts and diversity indexes for particulate organic matter in stratigraphically well-constrained (inoceramid biostratigraphy) sections is applied in monotonous Upper Cretaceous carbonate-siliciclastic sediments of southern Poland. Integrated data allow for the estimation of the proximity of an uplifted area from the studied sections. For the first time in palynofacies analysis, both Simpson's Index of Diversity $(1-\mathrm{D})$ and Shannon's index are used for organic matter distribution providing a comprehensive understanding of a proximaldistal trend in a sedimentary basin. Cluster analysis allowed grouping the samples within proximal to distal shelf zones. The size analysis of opaque woody phytoclasts is used to extrapolate the distance from the source area. Palynofacies analysis indicates the existence of an uplifted area (probably connected with "Kukernitz Island") in the Holy Cross part of the Danish-Polish Trough during the Maastrichtian. The presented results improve contemporary paleogeographical interpretations for this part of the Late Cretaceous central European Basin. The youngest Maastrichtian deposits of the
\end{abstract}

Electronic supplementary material The online version of this article (doi:10.1007/s10347-017-0509-9) contains supplementary material, which is available to authorized users.

Agata Jurkowska

jurkowska.a@gmail.com

Marcin Barski

marbar@uw.edu.pl

1 Faculty of Geology, Geophysics and Environmental Protection, AGH University of Science and Technology, Mickiewicza 30, 30-059 Krakow, Poland

2 Faculty of Geology, University of Warsaw, Żwirki i Wigury 93, 02-089 Warsaw, Poland
Miechów Synclinorium are described, based on inoceramids which are of early Late Maastrichtian age.

Keywords Palynofacies - Inoceramid stratigraphy · Paleogeography $\cdot$ Late Cretaceous · Central European Basin

\section{Introduction}

The Maastrichtian deposits of the present-day Miechów Synclinorium territory were accumulated in a shallow epicontinental sea. The monotonous succession of sandy chalk was deposited in a calm low-energy environment with a moderate rate of sedimentation. Although carbonate sedimentation prevailed, a high admixture of quartz grains (Rutkowski 1965; Jurkowska 2016) and the occurrence of well-preserved plant fossils (Cieslinski and Milacovic 1962; Halamski 2013) indicate the presence of an uplifted area in close proximity. Rutkowski (1960) indicated the WWS-EEN direction of terrigenous grains transport based on size measurement of quartz grains in Maastrichtian deposit in the SW part of the Miechów Synclinorium. Świdrowska et al. (2008) pointed out that during the Maastrichtian, terrigenous material was transported to the deeper basin on the SW slope of the Holy Cross segment from the SW without reaching the SE part of the Miechów Synclinorium. Although both studies present the possible direction of terrigenous grain transport, they do not indicate the source area of the material and focus of the whole Maastrichtian stage, without detailed stratigraphy available.

The presence of an uplifted area called "Kukernitz Island" in Ukraine (Pasternak et al. 1987) near the Holy Cross Mountains part of the Danish-Polish Trough during the Turonian-Campanian is well documented, the existence 
of the island during the Campanian-Maastrichtian is mentioned in the literature (Gierliński 2015; Bojanowski et al. 2017), but has not been explored in detail. Understanding the development of the Miechów Synclinorium is critical for the interpretation of the tectonic evolution of extra-Carpathian Poland and important for deciphering the final stages (Campanian or Maastrichtian) of the inversion history of the Danish-Polish Trough (Marcinowski 1974; Walaszczyk 1992; Kutek 1996; Krzywiec 2006).

Initially, the palynofacies analysis principles of Tyson (1993) as well as others revised by Roncaglia and Kuijpers (2006) and Zobaa et al. (2015) have been applied by us to recognize the sedimentary environment of the studied area. However, the unusual distribution pattern of marine phytoplankton decreasing offshore in the samples analyzed revealed that these models are inadequate for the presented case study. The paper presents the application of an integrated palynological study and palynofacies analysis supported by size analysis of opaque phytoclasts and diversity indexes for particulate organic matter in stratigraphically well-constrained (inoceramid biostratigraphy) sections. This method seems to be valuable in determining the distance from land in monotonous carbonate-siliciclastic sediments devoid of unequivocal sedimentological and paleontological data determining depositional environments.

\section{Geological setting}

The Miechów Synclinorium is positioned in the southeastern part of the Szczecin-Miechów Synclinorium (Fig. 1a), adjacent to the Mid-Polish Anticlinorium interpreted as an inverted part of the former Danish-Polish Trough (e.g., Pożaryski et al. 1979). The Cretaceous Miechów Synclinorium deposits, which are of Albian to Maastrichtian age (Rutkowski 1965; Marcinowski 1974; Walaszczyk 1992; Jurkowska 2016), overlay the Jurassic substrate unconformably, and are covered in their central and southern parts by Miocene deposits of the Carpathian Foredeep (Pozaryski 1977). The studied sections (Fig. 1b) present an almost complete succession ranging in age from the Lower Maastrichtian to the lower Upper Maastrichtian, and are represented by marly chalk in the lower part and sandy chalk with marly intercalations in the upper part (Rutkowski 1965; Jurkowska 2016). An increasing input of terrigenous quartz continuing within the succession has been noted by Jurkowska (2016). Under an optical microscope, the studied rocks represent packstone with sponge spicules and foraminifera with a significant admixture of terrigenous quartz (Rutkowski 1960; Jurkowska2016).

The existence of an uplifted area of the Danish-Polish Trough (present Mid-Polish Anticlinorium) called "Kukernitz Island" (Pasternak 1959; Pasternak et al. 1987) or
Łysogóry-Dobruga Land (Samsonowicz 1925; Pozaryski 1962) during the Turonian-Santonian is well documented and recently confirmed by micropaleontological (Dubicka et al. 2014) and ammonites data (Remin and Marshall 2016). Its formation was an effect of Subhercynian tectonic movements. The island probably expanded during the Santonian and Middle and Late Campanian (Świdrowska et al. 2008; Gierliński 2015; Walaszczyk and Remin 2015; Remin and Marshall 2016; Bojanowski et al. 2017). The uplifted areas in the Holy Cross part of the Danish-Polish Trough were an alimentation area for the Miechów Synclinorium, where increasing siliciclastic input was noted from the Late Campanian onwards (Jaskowiak-Schoeneichowa and Krassowska 1988; Jurkowska 2016).

\section{Localities and inoceramid succession}

The Maastrichtian succession of the Miechów Synclinorium is accessible through a series of natural and artificial (abandoned quarries) exposures. One of the authors (Jurkowska 2016) described the inoceramid stratigraphy and provided the coordinates of the most thoroughly studied sections. In this paper, new exposures and new stratigraphic data are also presented. The studied succession belong to the Endocostea typica and Trochoceramus radiosus zones of the Lower and Upper Maastrichtian.

\section{Lower Maastrichtian (Fig. 2)}

\section{Endocostea typica Zone}

The lowermost part of the E. typica Zone is represented by a glauconitic horizon in the SW part of the Miechów Synclinorium (Jurkowska 2016). In the NW part of the studied area, it is represented by marly fossiliferous chalk in the Pełczyska section (Fig. 1b) with many Endocostea typica (Whitfield 1877), and small $(<3 \mathrm{~cm})$ Cataceramus subcircularis (Meek 1876) specimens. The Dziewięcioły, Brynica Mokra, Pińczów, and Kozubów localities (Fig. 1b) were described by Jurkowska (2016) and the rocks are composed of white sandy chalk of the upper part of the E. typica Zone with numerous small $(3-5 \mathrm{~cm})$ representatives of $C$. subcircularis, Cataceramus barabini (Morton 1834), and Cataceramus glendivensis (Walaszczyk et al. 2001).

\section{Trochoceramus radiosus Zone}

New findings of Trochoceramus radiosus specimens from Wola Chroberska, Strzeżów 2, and Rzędowice (Jurkowska 2016) (Fig. 1b) confirmed that these sections represent the lower part of the $T$. radiosus Zone. In the Jelcza Wielka (Peryt and Dubicka 2009; Jurkowska 2016) and Michałów 


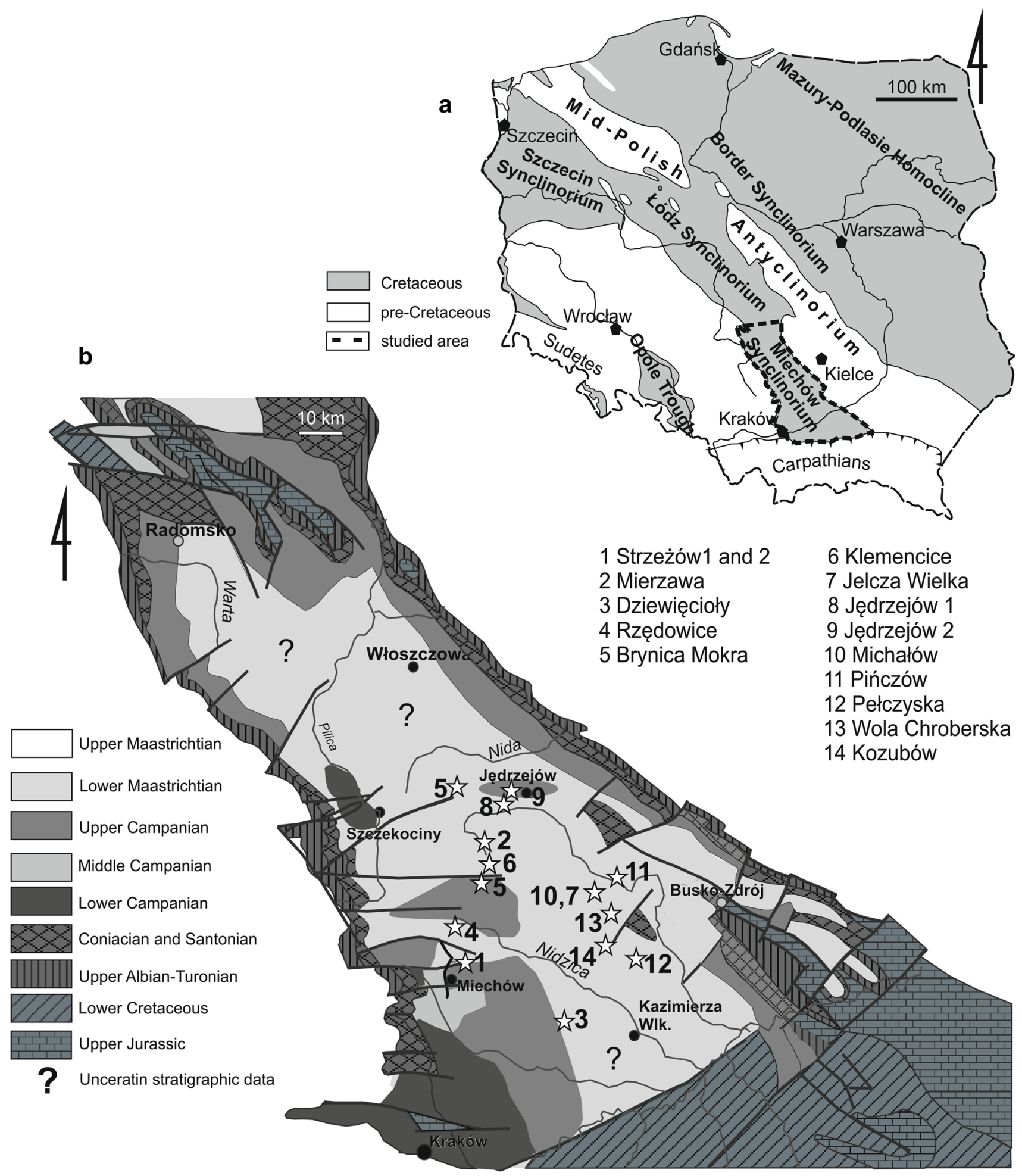

Fig. 1 a Tectonic-sketch map of Poland (without Cenozoic cover) (after Pożaryski 1974; changed after Zelazniewicz 2008 and Zelazniewicz et al. 2011; Jurkowska 2016). b Geological map of the Miechów Synclinorium (modified after Dadlez et al. 2000 and Jurkowska 2016) with studied localities 


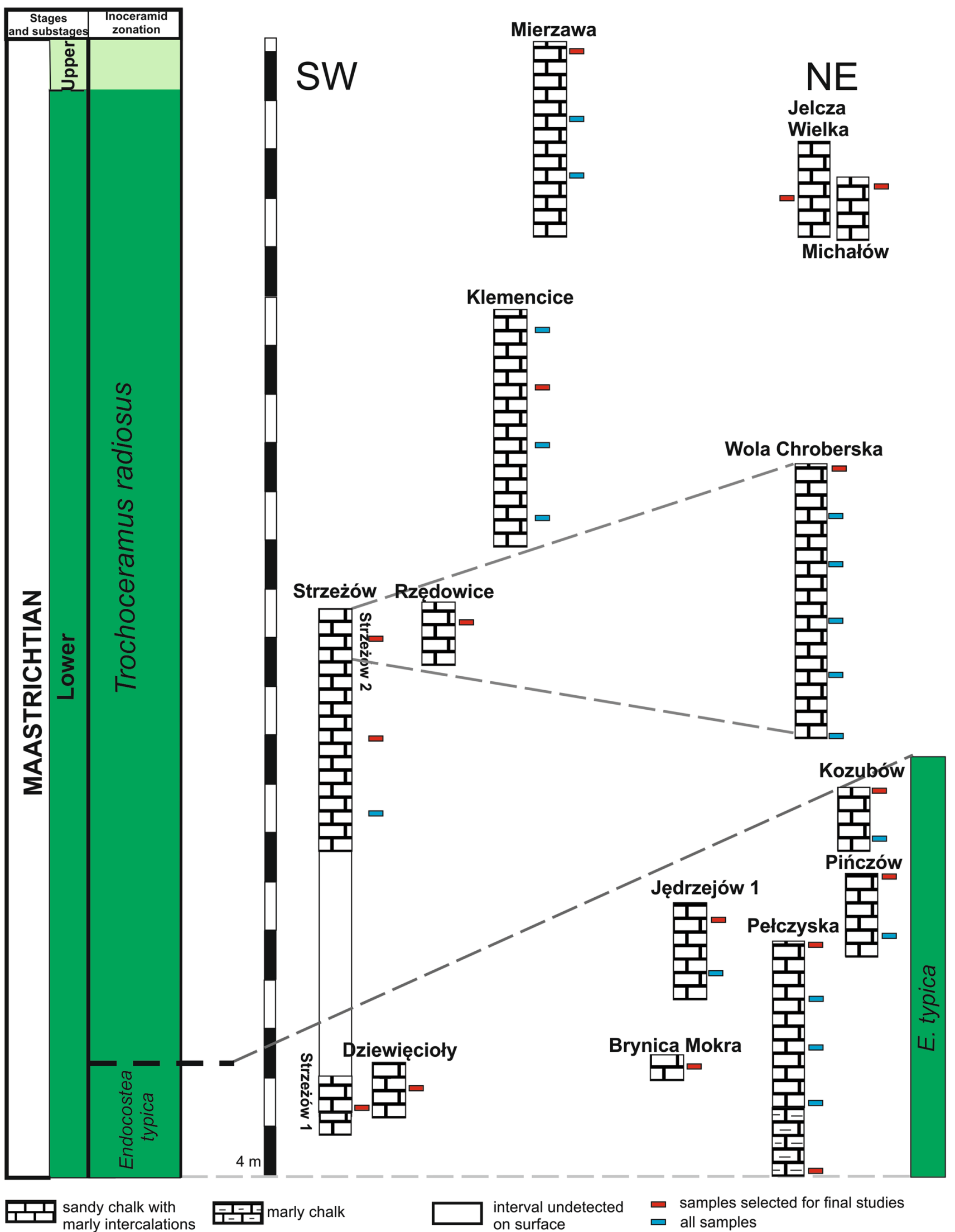

Fig. 2 Geological columns, stratigraphy (correlation of inoceramid zonation applied herein (after Walaszczyk et al. 2009, 2010, 2016) of the Upper Maastrichtian of studied area (Jurkowska 2016; this paper) 
(Jurkowska 2016) sections, new findings of Spyrideoceramus tegulatus (Von Hagenow 1842) forma A indicate the upper part of the $T$. radiosus Zone.

Jędrzejów 1 [N50³7'51.26"E20¹7'37.05"] and Klemencice $\left[\mathrm{N} 50^{\circ} 32^{\prime} 31.89^{\prime \prime} \mathrm{E} 20^{\circ} 11^{\prime} 53.47^{\prime \prime}\right]$ (Fig. 1b) are newly studied sections and are exposed at the temporary road cutting from Świątniki to Jędrzejów. In Jędrzejów 1 (Fig. 1b), sandy white chalk with abundant inoceramids is exposed, and specimens of $C$. subcircularis $(3-4 \mathrm{~cm})$ of the upper part of the E. typica Zone were recognized. In Klemencice, yellow, highly sandy chalk with a large number of $C$. subcircularis (6-9 cm) (Fig. 3a), C?. glendivensis (Fig. 3b), Trochoceramus cf. thomasi (Walaszczyk, Kennedy, Klinger, 2009), Platyceramus cf. salisburgensis (Fugger and Kastner, 1885) (Figs. 3g, 4a), and C. barabini were noted. Based on the inoceramid fauna, the section represents the upper part of the $T$. radiosus Zone (Walaszczyk et al. 2009, 2010).

\section{Upper Maastrichtian (Fig. 2)}

\section{Trochoceramus radiosus Zone}

The newly studied Mierzawa section [N50'34'5.48" E20 $13^{\prime} 2.44^{\prime \prime}$ (Fig. 1b) represents the youngest Upper Cretaceous blue and yellow highly sandy chalk of the Miechów Synclinorium. A rich inoceramid fauna composed of Spyridoceramus tegulatus (Von Hagenow, 1842) forma A (only in the lowermost part of the section) (Fig. 3e), Spyridoceramus tegulatus (Von Hagenow, 1842) forma B (see: Walaszczyk et al. 2010) (Fig. 3f), Cataceramus cf. subcircularis (Meek 1876) (see: Walaszczyk et al. 2010) (Fig. 3c), and a single representative of 'Inoceramus' cf. ianjoaensis morgani (Sornay 1973) (Fig. 3d), indicating the highest part of the T. radiosus Zone.

\section{Inoceramid succession}

In inoceramid terms, the studied succession comprises an interval from the E. typica to the $T$. radiosus Zone. In the E. typica Zone, the index taxon was noted only in the lowest part of the zone, while above this only a mass occurrence of small $(<4 \mathrm{~cm}) C$. subcircularis and $C$. barabini was observed. In the uppermost part of the zone, representatives of $C$. subcircularis and $C$. barabini occur together with $C$. glendivensis. A gradual size increase of $C$. subcircularis is observed within the E. typica and $T$. radiosus zones. The $E$. typica Zone could be informally divided into a lower (with index taxon) and upper assemblage (with numerous small representatives of a Cataceramus Assemblage).

The index taxon of the $T$. radiosus Zone was noted only in the lower part of the zone, while a few meters above the FO of $T$. radiosus, a single representative of $S$. tegulatus forma A was observed (Jurkowska 2016). Above this, numerous representatives of $C$. subcircularis $(6-9 \mathrm{~cm}), C$. ? glendivensis, $C$. barabini, T. ?thomasi, and $P$. cf. salsiburgensis occur. The $T$. radiosus Zone could be informally subdivided into a lower assemblage with the index taxa (Trochoceramus Assemblage) and an upper one without them (Cataceramus Assemblage) (Walaszczyk et al. 2010). In the highest part of the studied succession, numerous representatives of $S$. tegulatus forma $\mathrm{B}$ (which is $4 \mathrm{~m}$ above mass occurrence of S. tegulatus forma A), C. cf. subcircularis $(6-9 \mathrm{~cm})$ and a single representative of 'I.' cf. ianjoaensis morgani were noted. The youngest assemblage represents the highest part of the $T$. radiosus Zone.

\section{Materials and methods}

The inoceramids were collected bed by bed from each section providing a detailed stratigraphic framework enabling lateral correlations of the sections representing a single inoceramid zone. The sandy chalk was deposited under stable paleoenvironmental conditions with no signs of strong sea bottom currents, erosion, and synsedimentary tectonic movements, and are preferable targets for palynofacies analysis (Tyson and Follows 2000) and allow for the reconstruction of the intact pattern of particulate organic matter in the sedimentary basin. Because it was practically impossible to distinguish isochronous facies transitions according to Walther's law, we decided to analyze most similar common and predominating lithology of sandy and marly chalk in all sections. On the one hand, it minimizes differential diagenetic imprint on organic matter while on the other it ignores the subtle fluctuation of the local environment, which is negligible for the present scale of observation.

Thirteen outcrops (Figs. 1b, 2) representing Lower Maastrichtian to lower Upper Maastrichtian sandy/marly chalk were selected for palynofacies analysis. The samples were collected every $3 \mathrm{~m}$ from all sections (Fig. 2). For the final palynofacies analysis, the 14 most representative and least weathered samples from each section have been selected.

The idea to compare samples from several sections, preferably representing the same inoceramid zone and encompassing the widest lateral distance, was essential for the present study. Therefore, only a restricted number of samples met the requirements due to the inaccessibility of other stratigraphically equivalent areas devoid nowadays of outcrops.

One hundred grams of each rock sample was treated with $37 \% \mathrm{HCl}$ and $40 \% \mathrm{HF}$ to remove carbonates and silicate minerals. Finally, the organic residue was neutralized on a sieve, the diameter of which was $15 \mu \mathrm{m}$, and condensed by heavy liquid $\left(\mathrm{ZnCl}_{2}, 2 \mathrm{~g} / \mathrm{cm}^{3}\right)$ separation. Two slides per sample were examined. Organic matter particles were 


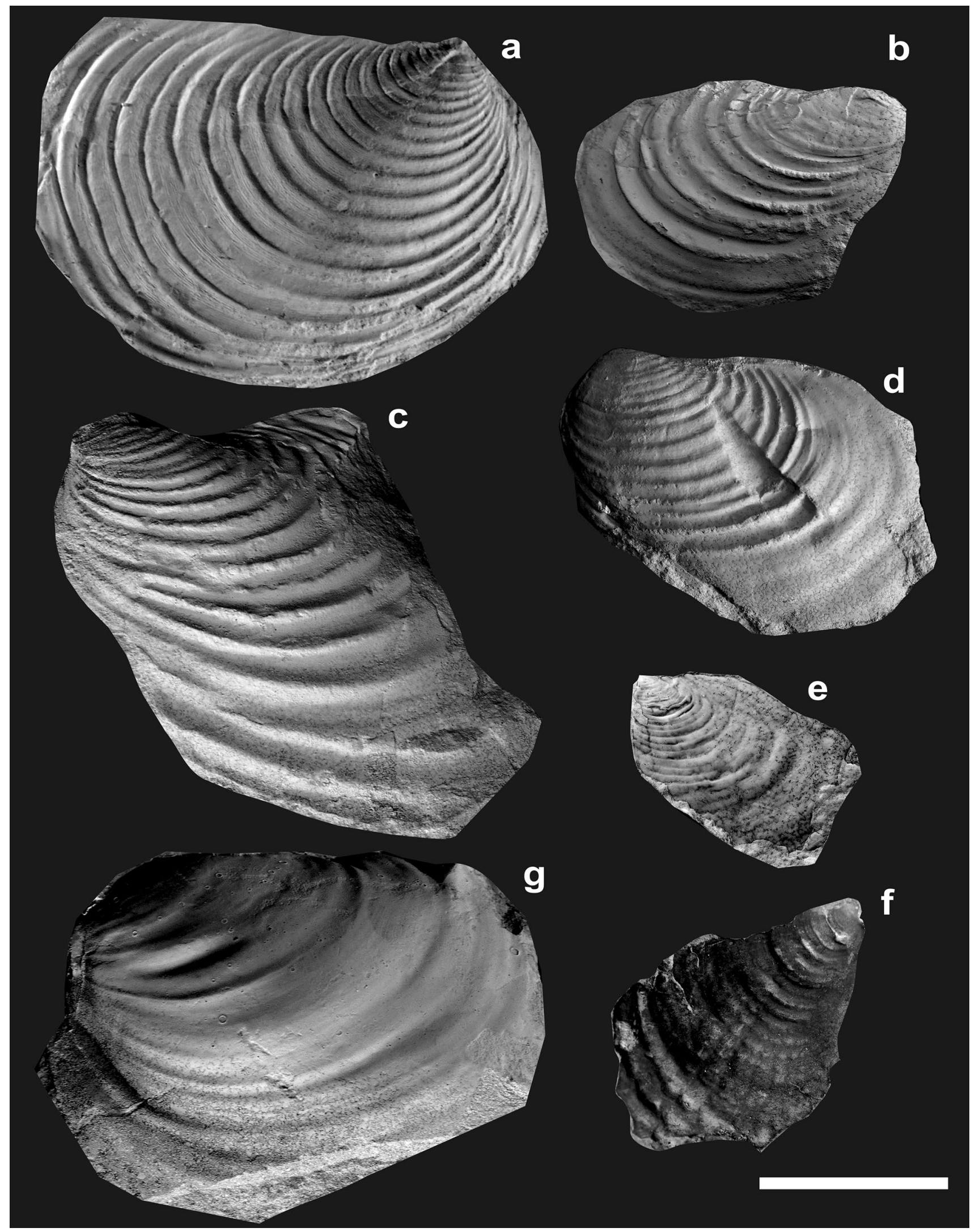


«Fig. 3 a Cataceramus subcircularis (Meek 1876), Klemencice, T. radiosus Zone; ZI/68/004. b Cataceramus? glendivensis Walaszczyk, Cobban and Harries, 2001, Klemencice, T. radiosus Zone; ZI/68/003. c Cataceramus cf. subcircularis (Meek 1876), Mierzawa, T. radiosus Zone; ZI/68/006. d 'Inoceramus' cf. ianjonaensis morgani Sornay, 1973, T. radiosus Zone; ZI/68/012. e Spyridoceramus tegulatus (Von Hagenow 1842) forma B, Mierzawa, T. radiosus Zone; ZI/68/009 f Spyridoceramus tegulatus (Von Hagenow 1842) forma A, Mierzawa, T. radiosus Zone; ZI/68/001. g Platyceramus cf. salisburgensis (Fugger and Kästner 1885), Klemencice, T. radiosus Zone; $\mathrm{ZI} / 68 / 015$. Scale bar $3 \mathrm{~cm}$

counted to 500 per sample. Microphotographs were taken using a Nikon Eclipse E-600 microscope equipped with phase contrast and a digital camera.

The palynofacies analysis, i.e., the classification of the main morphological components, follows the categories established by Tyson (1993, 1995). Late Cretaceous dinoflagellate assemblages are analyzed only for qualitative purpose, as the gonyalacoid type of cysts which predominate the samples are not characteristic for specific environmental conditions.

The measurements of opaque phytoclasts have been performed using a $\times 40$ microscope objective and a reticule. One hundred phytoclasts from each sample were counted. The shape of the clasts has been approximated to square or rectangular forms, and their respective edges have been measured. Following Tyson (1993), opaque phytoclasts with a length-width ratio higher than 3.0 have been classified as lath-shaped. Maximum and minimum clast size values are also presented to estimate the sorting ratio and distance from the shoreline. The Simpson's Index of Diversity $(1-D)$ and Shannon's diversity index diagram are provided for organic matter diversity reflecting proximal-distal position of the studied sections along the carbonate shelf.

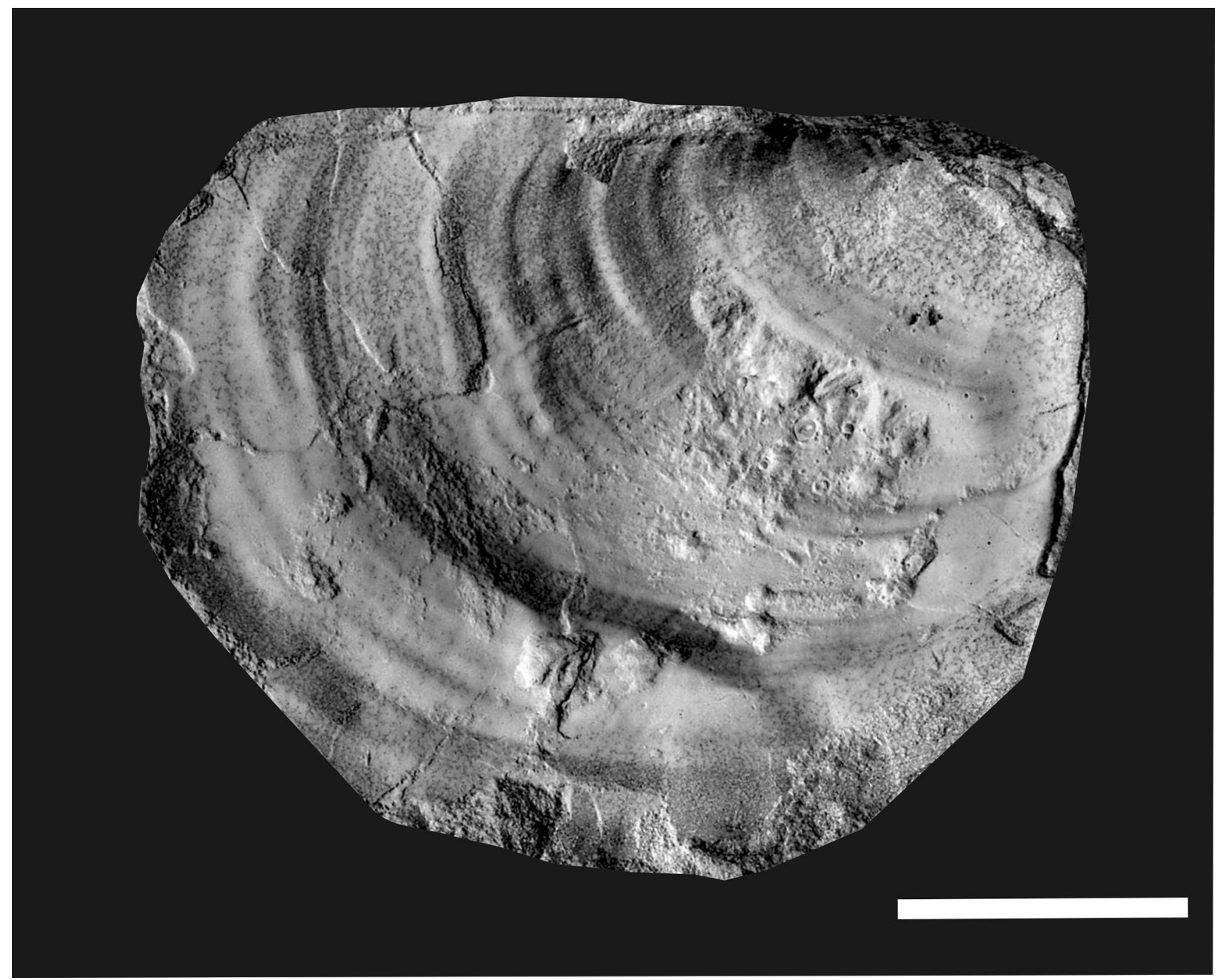

Fig. 4 Platyceramus cf. salisburgensis (Fugger and Kästner 1885), Klemencice, T. radiosus Zone; ZI/68/013. Scale bar $3 \mathrm{~cm}$ 


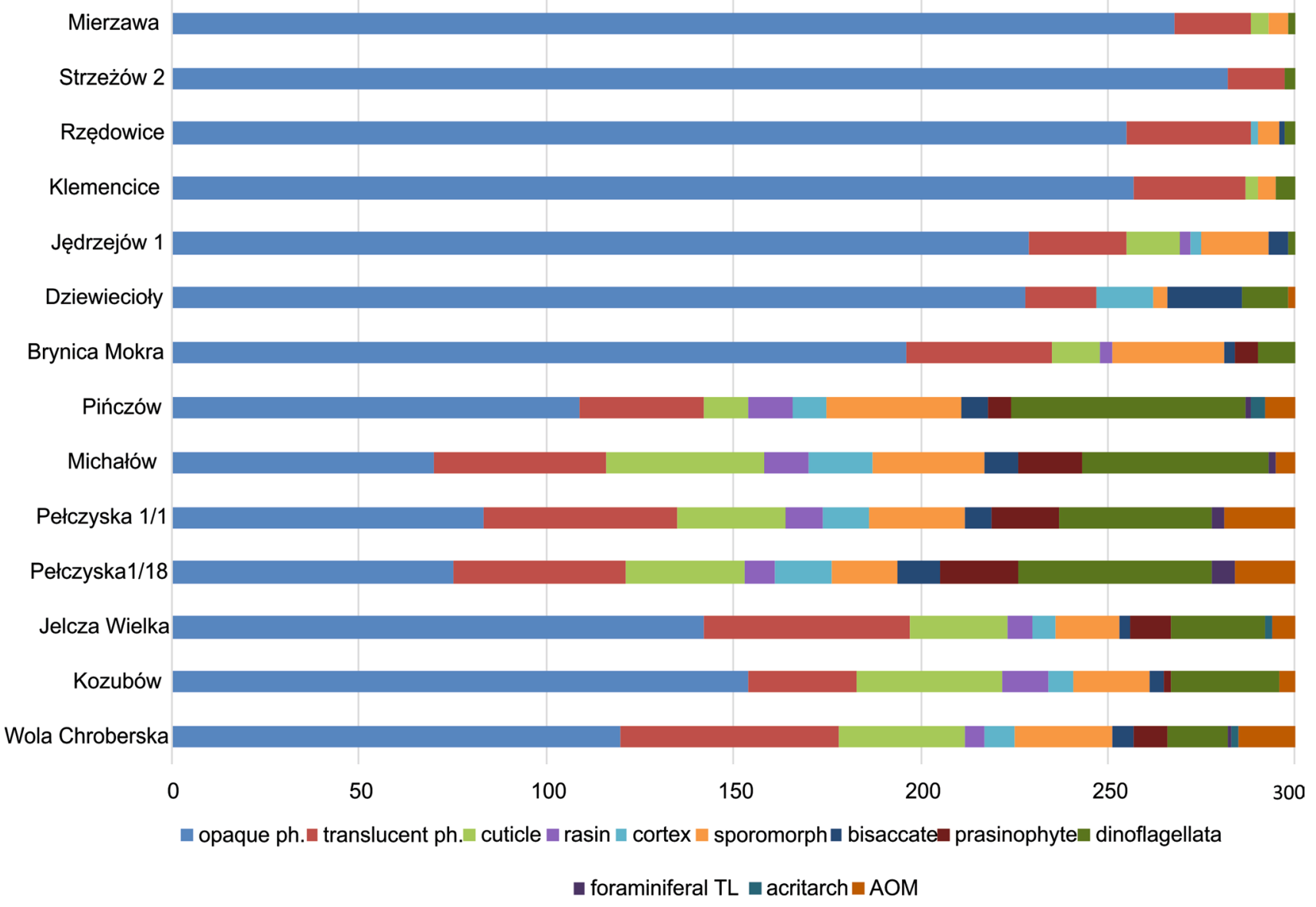

Fig. 5 Quantitative palynofacies data from the studied samples

\section{Palynofacies associations—cluster analysis}

Based on the palynofacies analysis (Fig. 5), two main groups and two subgroups (Fig. 6) related to the facies distribution along the shelf are distinguished within the E. typica and $T$. radiosus zones. The groups are created automatically by hierarchical clustering provided by the PAST software package (Hammer et al. 2001). The "unweighted pair-group average" (UPGMA) algorithm has been applied with the Euclidean similarity index to ensure the best results. The Cohen's kappa coefficient for the cluster analysis was 0.8535 , which reflects an almost perfect agreement. Two major groups of palynofacies and one subgroup have been distinguished on the distance level of ca. 145 (Fig. 6). Minor internal difference of the first group could be explained by natural fluctuations of palynofacies components in shore vicinity and close geographical location (Müller 1959; Traverse 1988; Tyson 1995).

The first palynofacies group (Fig. 7a-d) has been recognized in samples from the Pełczyska (1/1 and 1/18), Pińczów, Kozubów, Wola Chroberska, Jelcza Wielka, and Michałów sections. All samples are characterized by a high abundance and diversity of particulate organic matter. They are also dominated by land-derived palynological components with a predominance of opaque phytoclast, pollen grains, as well as large and intact cuticle particles, resin, and cortex. Additionally, prasinophyte algae (Tasmanites sp., Pterospermella sp.) (only in Pełczyska, Kozubów, and Michałów) and chlorococcale algae (Botrycoccus sp., Palambages sp.) (Pełczyska) have been recognized. Marine palynomorphs are moderately abundant, and are mostly represented by dinoflagellate cysts especially in the Pełczyska (1/1 and 1/18), Pińczów and Michałów sections. This leads to an internal diversification of this palynofacies group in terms of clustering (Fig. 8). Moreover, the samples from Pełczyska $1 / 1$ and Pełczyska $1 / 18$ show noticeable admixtures of foraminifera test linings and a noticeable content of amorphous organic matter (AOM), which also predominates the samples from Wola Chroberska.

The predominance of the phytoclast group with a high content of opaque particles is the key feature of the second group. Within this group, two subgroups have been distinguished. The first subgroup (Figs. 7e, f; 8a-c) is recognized in the sections Brynica Mokra, Dziewięcioły, Jędrzejów 1, and is characterized by features typical for the second group, 
Fig. 6 Dendrogram (r-mode) of the palynofacies from outcrops studied showing the three distinctive environmental groups

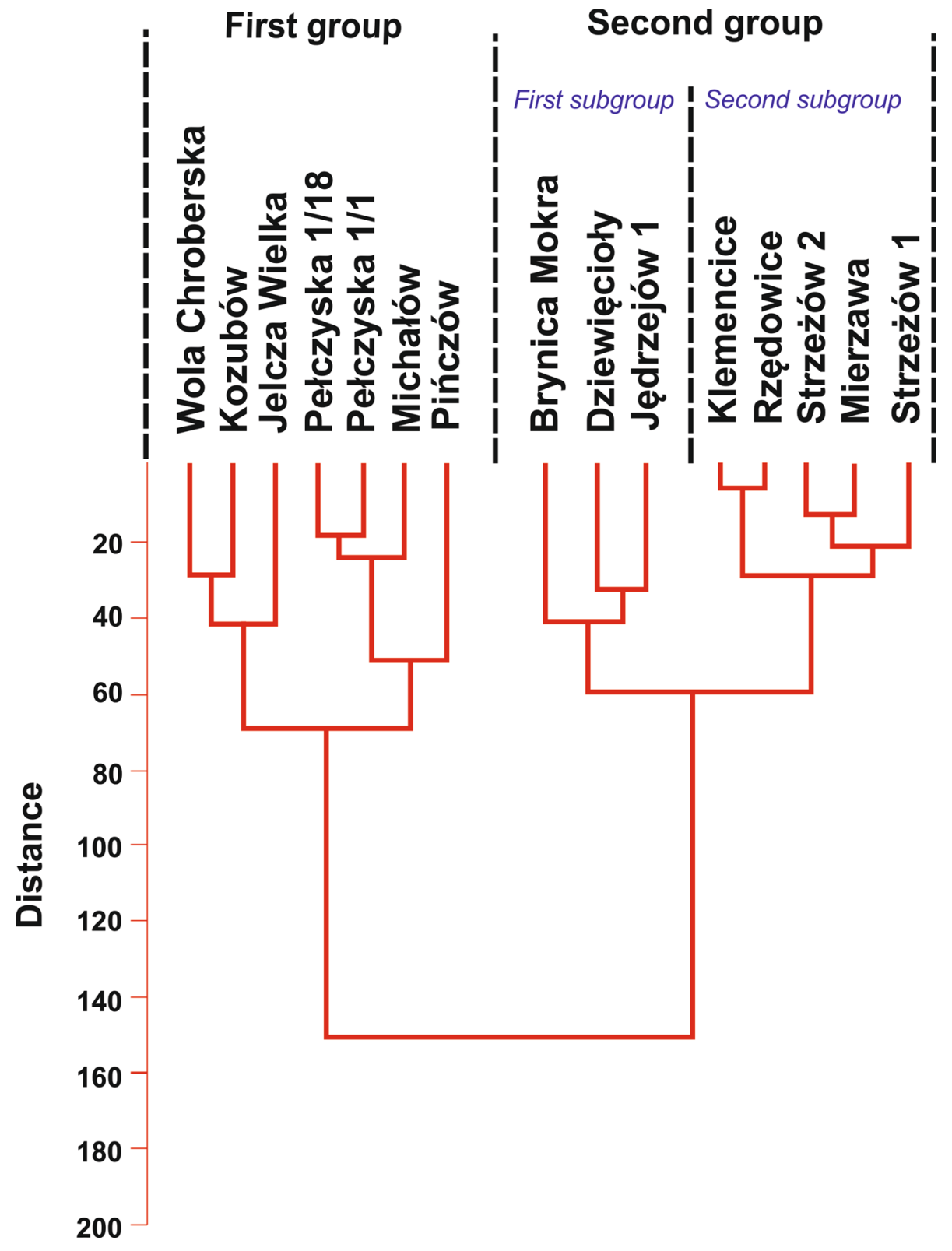

but a moderate content of translucent phytoclast and sporomorphs is also noted. Cuticle, resin, and single-cortex tissues are present, but with conspicuously declining tendency. Marine plankton content represented by dinoflagellate cyst is noticeable. The samples from Dziewięcioły are unique as they contain large quantities of bisaccate pollen grains.

The second subgroup of the second group (Fig. 8d-f) is encountered in the Strzeżów 1 and 2, Rzędowice, Klemencice, and Mierzawa sections, and is characterized by a predominance of the phytoclast group with high content of opaque particles. Translucent particles are mainly composed of brown structured wood tissue. Dinoflagellate cysts are noted in all samples.
To understand the provenience of the palynofacies grouped by cluster analysis, the widely used plots of Tyson (1993, 1995) and further modification of Roncaglia and Kuijpers (2006) and Zobaa et al. (2015) have been used. Tyson's (1993) ternary diagram revealed the concentration of the studied samples within fields I and III (Fig. Online Resource 1). According to the definition, they represent "highly proximal shelf or basin" and "heterolithic oxic shelf (proximal shelf)" environments, respectively. In this way, the most diverse palynofacies associations from the first group have been placed in the "proximal shelf" environment field and the second group with monospecific high content of opaque particles in the "highly proximal 

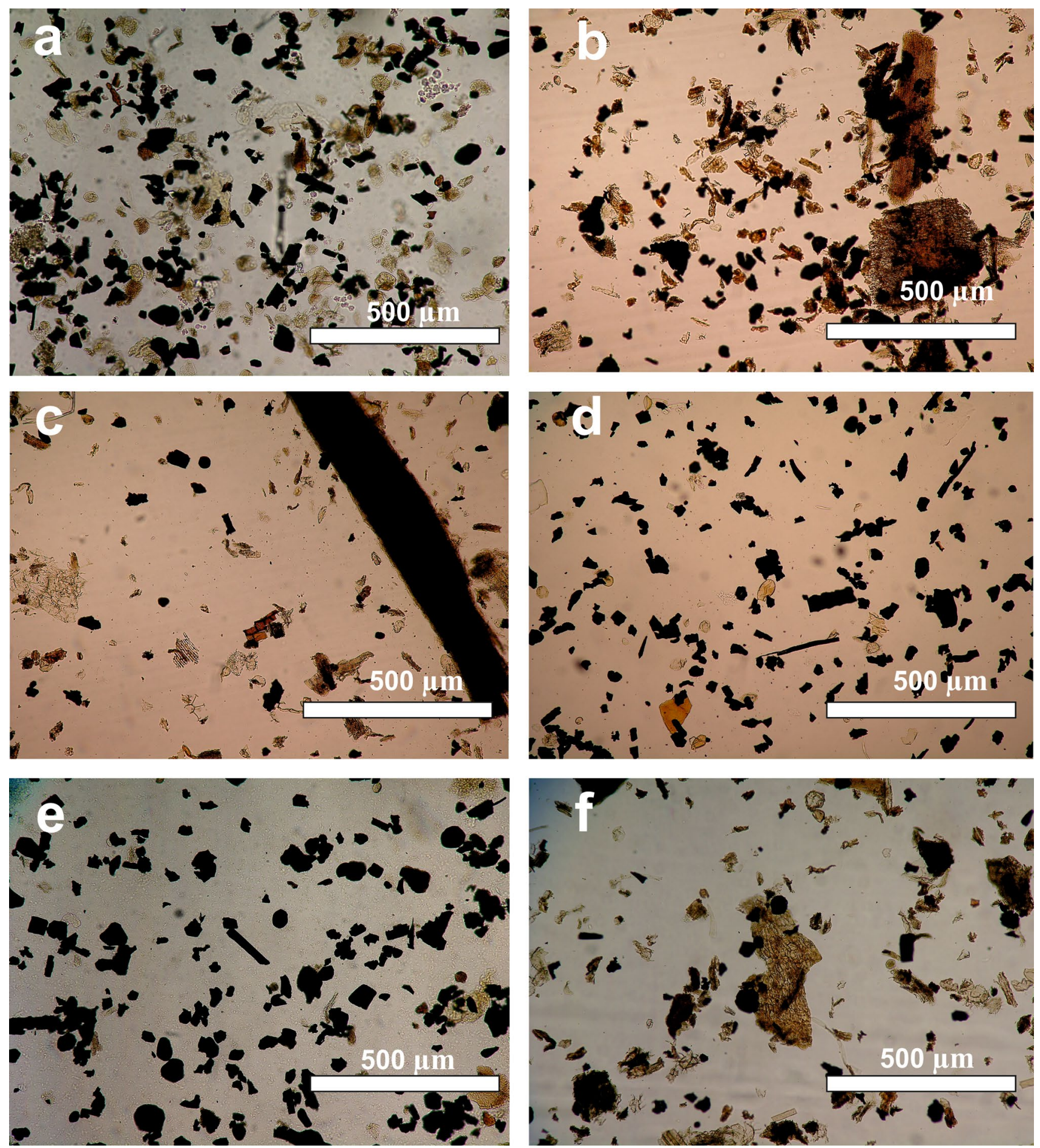

Fig. 7 Microscopic photographs of the most representative palynofacies of studied sections. Scale bar of $500 \mu \mathrm{m}$ valid for all captions. First group (proximal palynofacies): a-c Pełczyska, d Pińczów, e Jelcza Wielka, f Michałów

shelf" field. The positions within the fields in the present study are evidently constrained by the content of marine palynomorphs with a major influence of the abundance dinoflagellate cysts.

\section{Palynofacies—diversity indexes}

Due to some discrepancies within the used palynofacies ternary plots (Tyson 1993, 1995; Roncaglia and Kuijpers 

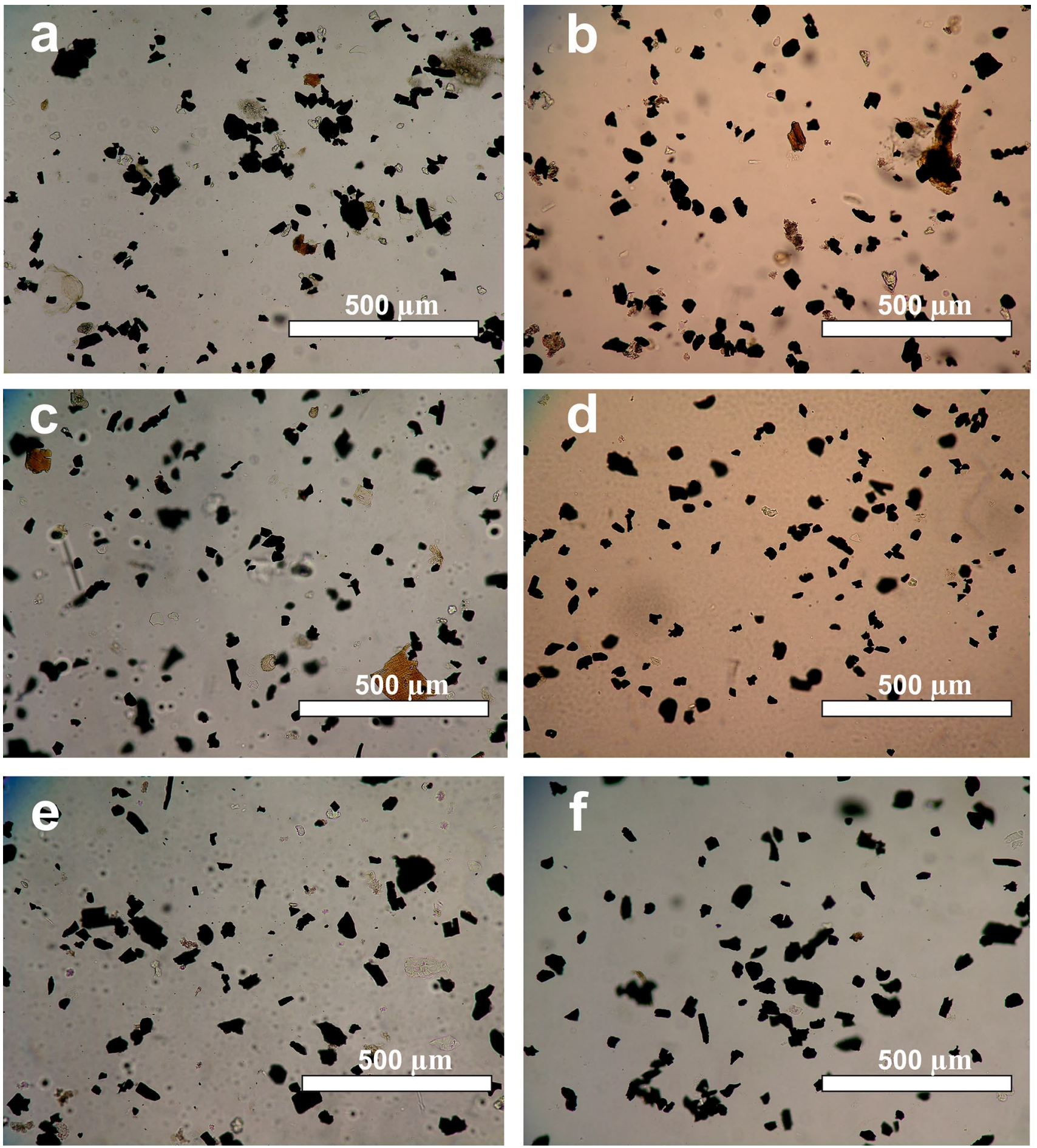

Fig. 8 Microscopic photographs of the most representative palynofacies of studied sections. Scale bar of $500 \mu \mathrm{m}$ valid for all captions. Second group-first subgroup (intermediate palynofacies): a Brynica

Mokra, b Dziewięcioły, c Jędrzejów 1; Second group-second subgroup (distal palynofacies) d Strzeżów1, e Mierzawa, f Strzeżów 1

2006), especially with respect to the identification of proximal-distal environments, diversity indexes of sedimentary organic matter have been calculated. Widely used diversity indexes in the ecological study are the Simpson's Index of
Diversity $(1-D)$ and the Shannon's diversity index, both of which have been used herein. The results of the diversity analysis are presented in the Fig. 9a, b, where the values of both indexes are plotted for all studied locations in ascending 

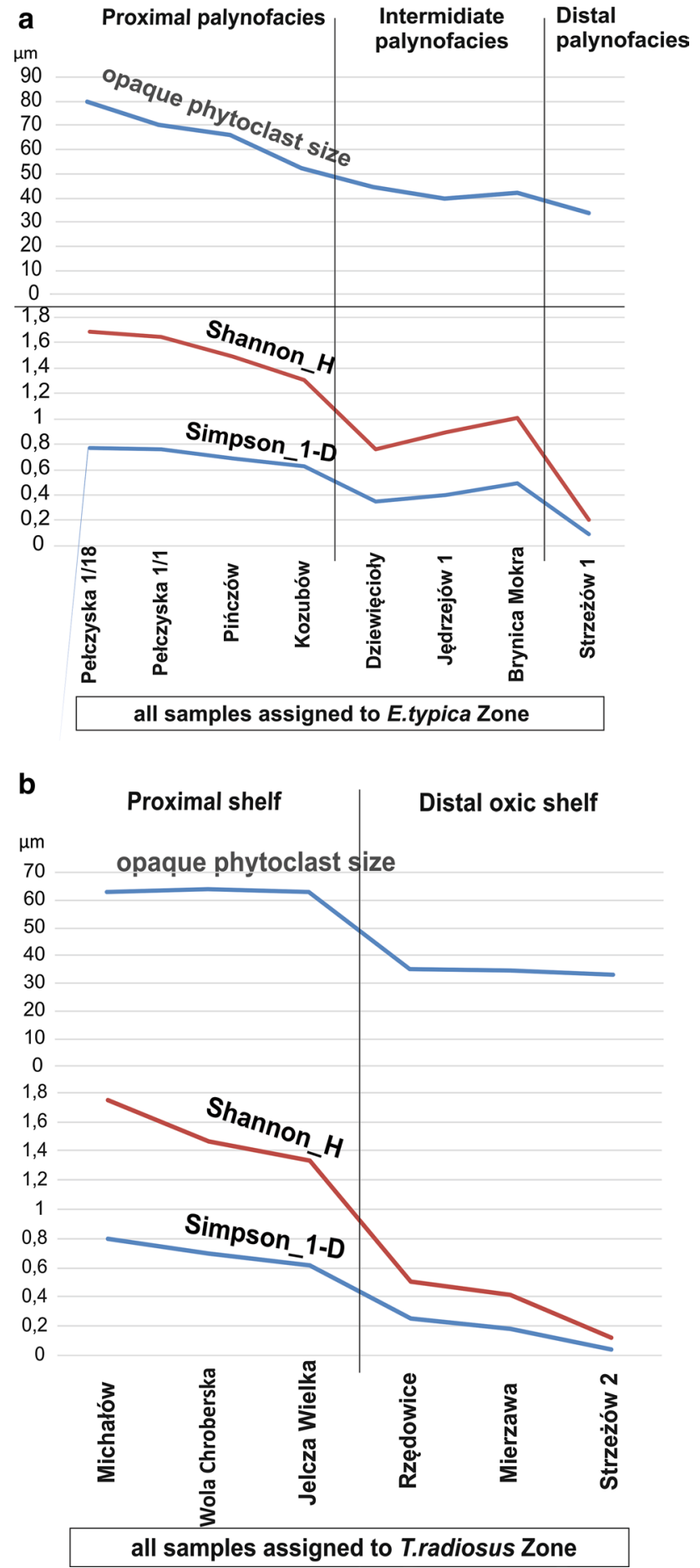

Fig. 9 a, b Lateral variations of opaque phytoclasts sizes and diversity indexes from two transects along distinguished palynofacies zones

order. Simpson's Index spans the values from 0.004 to 0.80 , and Shannon's index from 0.12 to 1.75 . In both cases, the increasing values of indexes coincide with a higher biodiversity connected to a more diversified palynological content.
The higher diversity of organic particles could also be interpreted as a proximity index to the source area (Müller 1959; Degens and Mopper 1976; Tyson 1993). The ranges of biodiversity constrained by the Simpson and Shannon indexes follow the three groups of palynofacies revealed by the cluster analysis (Fig. 6). The boundaries between the diversity groups are sharply distinguishable by the Shannon index values (Fig. 9a, b). The boundary between less diversified and intermediate palynofacies groups run across 0.507 and 0.681 and between intermediate and most diversified palynofacies across 1.003 and 1.334 of the Shannon index. Subsequently, general diversity indexes for all samples are tested for time intervals of the samples assigned to the Maastrichtian E. typica and T. radiosus zones separately (Fig. 9a, b). For the E. typica Zone, three generations of index values are discernible with the boundaries placed between the Kozubów-Dziwięcioły and the Brynica Mokra-Strzezów 2 sections. These indexes reflect three sedimentary zones within a basin with westwards-declining diversity of organic matter. A similar trend is observed for the T. radiosus Zone, however only two diverse populations were noted.

\section{Distance from the shoreline—opaque phytoclasts' size}

The size analysis of opaque phytoclasts used for evaluation of the distance (Tyson and Follows 2000) from the shoreline is presented in Fig. 9a, b. The actual distance of $35 \mathrm{~km}$ between analyzed areas approximates the original sedimentary distances in the basin with relation to the shoreline (Figs. 4, 6). Mean values of opaque phytoclast sizes from samples collected from all analyzed sites range from $80 \mu \mathrm{m}$ to about $35 \mu \mathrm{m}$ (Fig. 9a, b). The study of samples revealed that quantitative variations in size, shape, and preservation of plant debris correlate with actual distance from the shoreline along shelf deposits. The opaque phytoclast size curve for the E. typica Zone shows a continuous but relatively steep trend of decreasing values from the Pełczyska to the Strzeżów 1 sections. The maximum value of $80 \mu \mathrm{m}$ for Pełczyska $1 / 18$ is related to a proximal position in the basin. The curve for the $T$. radiosus Zone, starting with a value of $62 \mu \mathrm{m}$ value for the Michałów section, reveals two populations of phytoclast size and a flat character. This probably expresses a more distal locality with respect to the terrestrial organic matter input and a more stable dispersal of organic particles offshore. When calculating opaque phytoclast sizes, the clear differences between maximum and minimum size ranges in the Pełczyska and Pińczów sections stood out. This trend decreased distally. According to Tyson (1993), this results from a low sorting value, characteristic for nearshore areas, which is a function of distance from the source area.

According to the size analysis of Tyson and Follows (2000), the 35- $\mu \mathrm{m}$ size of the opaque phytoclast 
Fig. 10 Qualitative distribution of dinoflagellate cyst in studied samples

\begin{tabular}{|c|c|c|c|c|c|c|c|c|c|c|c|c|c|c|}
\hline & $\begin{array}{l}\frac{\pi}{2} \\
\frac{2}{0} \\
\sum_{0}^{0} \\
\frac{0}{2} \\
\frac{1}{2}\end{array}$ & $\begin{array}{l}\frac{7}{0} \\
\frac{0}{0} \\
\frac{d}{N} \\
\frac{0}{N}\end{array}$ & 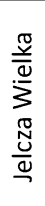 & 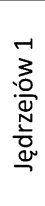 & 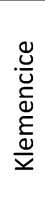 & 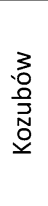 & $\begin{array}{l}\frac{3}{0} \\
\frac{0}{10} \\
\frac{c}{0} \\
\frac{.0}{\Sigma}\end{array}$ & 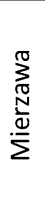 & 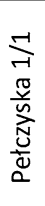 & 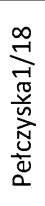 & 胥 & 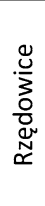 & 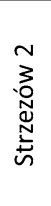 & 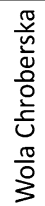 \\
\hline Achomosphaera sp. & & & & & & & & & $\mathbf{x}$ & $\mathbf{x}$ & & & & \\
\hline Alterbidinium sp. & & & & & & & & & $\mathbf{x}$ & $\mathbf{x}$ & & & & \\
\hline Apteodinium delicatum & & & & & & & & & & & $\mathbf{x}$ & & & \\
\hline Areoligera coronata & & & & & & & $\mathbf{x}$ & & & & $\mathbf{x}$ & & & \\
\hline Areoligera senonensis & & & & & & & $\mathbf{x}$ & & & & & & & \\
\hline Areoligera $\mathrm{sp}$. & $\mathbf{x}$ & $x$ & $\mathbf{x}$ & & & & & & & & $\mathbf{x}$ & & & $\mathbf{x}$ \\
\hline Biconidinium reductum & & & & & & & & & & & $\mathbf{x}$ & & & \\
\hline Botrycoccus sp. & & & & & & $x$ & $x$ & & $x$ & $x$ & & & & \\
\hline Cerodinium diebelii & & & & & & & & & $\mathbf{x}$ & $\mathbf{x}$ & & & & \\
\hline Circulodinium distinctum & & & & & & & & & & & $x$ & & & \\
\hline Cleistosphaeridium sp. & & & $x$ & & & & & $x$ & & & $\mathbf{x}$ & & $\mathbf{x}$ & $x$ \\
\hline Dinogymnium acuminatum & & & & & & & & & $\mathbf{x}$ & $\mathbf{x}$ & & & & \\
\hline Dinogymnium longicorne & & & & & & & & & $\mathbf{x}$ & & & & & \\
\hline Florentinia aculeata & & & & & & & & & & $\mathbf{x}$ & & & & \\
\hline Glaphyrocysta sp. & $x$ & & $x$ & & $\mathbf{x}$ & & & $\mathbf{x}$ & & & $\mathbf{X}$ & & & $\mathbf{x}$ \\
\hline Heterosphaeridium sp. & $x$ & & & $x$ & $\mathbf{x}$ & & $\mathbf{x}$ & $x$ & $x$ & $\mathbf{x}$ & $\mathbf{x}$ & & & $x$ \\
\hline Hystrichosphaeridium sp. & & & & & & & & & $\mathbf{x}$ & $\mathbf{x}$ & $\mathbf{x}$ & & & \\
\hline Isabelidinium $\mathrm{sp}$. & & & & & & & & & $\mathbf{x}$ & $\mathbf{x}$ & & & & \\
\hline Kiokansium polypes & & & & & & & $\mathbf{x}$ & & & & & & & \\
\hline Kiokansium sp. & $\mathbf{X}$ & $\mathbf{x}$ & $\mathbf{x}$ & & $\mathbf{x}$ & $\mathbf{x}$ & $\mathbf{x}$ & $\mathbf{x}$ & & & $\mathbf{x}$ & & $\mathbf{x}$ & $\mathbf{x}$ \\
\hline Membranilarnacia sp. & & & & & & & & & & & $\mathbf{x}$ & & & \\
\hline Odontochitina operculata & & & & & & & & & & & $\mathbf{x}$ & & & \\
\hline Odontochitina sp. & & & & & & & & & & & $\mathbf{x}$ & & & \\
\hline Oligosphaeridium complex & & & & & & & & & $\mathbf{x}$ & $\mathbf{X}$ & & & & \\
\hline Oligosphaeridium complex & & & & & & & $\mathbf{x}$ & & & & & & & \\
\hline Operculodinium sp. & & & & & & & $\mathbf{x}$ & & & & & & & \\
\hline Palaeocystodinium sp. & & & & & & & & & $\mathbf{x}$ & $\mathbf{x}$ & & & & \\
\hline Palambages sp. & & & & & & & & & & $\mathbf{x}$ & & & & \\
\hline Palynodinium grallator & & & & & & & & & $\mathbf{x}$ & $\mathbf{x}$ & & & & \\
\hline Pervosphaeridium sp. & & & & & & & & & & & $\mathbf{x}$ & & & \\
\hline Pterospermella sp. & & & & & & $\mathbf{x}$ & $\mathbf{x}$ & & $\mathbf{x}$ & $\mathbf{x}$ & & & & \\
\hline Riculacysta sp. & $\mathbf{x}$ & & & & & & & & & & & & & \\
\hline Spinidinium eggeri & & & & & & & & & $\mathbf{x}$ & & & & & \\
\hline Spiniferites ramosus & & & & & & & & & $\mathbf{x}$ & $\mathbf{x}$ & & & & \\
\hline Spiniferites sp. & $\mathbf{x}$ & & $\mathbf{x}$ & & $\mathbf{X}$ & & & & & & $\mathbf{x}$ & $\mathbf{x}$ & $\mathbf{x}$ & $\mathbf{x}$ \\
\hline Spongodinium delitiense & & & & & & & & & $\mathbf{x}$ & $\mathbf{x}$ & & & & \\
\hline Surculosphaeridium longifurcatum & & & & & & & & & $\mathbf{x}$ & $\mathbf{x}$ & $\mathbf{x}$ & & & \\
\hline Tasmanites sp. & & & & & & & & & $\mathbf{x}$ & $\mathbf{x}$ & & & & \\
\hline
\end{tabular}

corresponds to a distance of $10 \mathrm{~km}$ from the shoreline. In our study, the same values occur in the sections situated at least approximately $20-35 \mathrm{~km}$ from inferred shoreline. This discrepancy is probably due to seafloor configurations and sedimentary basin character for both case studies.

\section{Phytoplankton assemblages}

Only a few samples from the studied material yield rich and diversified phytoplankton assemblages (Fig. 10). They are represented by autotrophic and heterotrophic dinoflagellates cysts, phycoma of prasinophytes, and colonies of chlorococcale algae (Fig. 11). The most diverse assemblages occur in the Pełczyska, Pińczów and Michałów sections. The Wola Chroberska, Kozubów, Jelcza Wielka, Brynica Mokra and Dziewięcioły sections are characterized by scarce phytoplankton content, whereas the Jędrzejów, Klemencice, Rzędowice, Strzeżów and Mierzawa sections are practically barren with records of only 2-5 specimens per slide.

\section{Discussion}

Cluster analyses of organic matter combined with palynofacies diversity and opaque phytoclast size analyses in stratigraphically well-constrained sections provide valuable data for paleogeographic reconstructions in monotonous Upper 

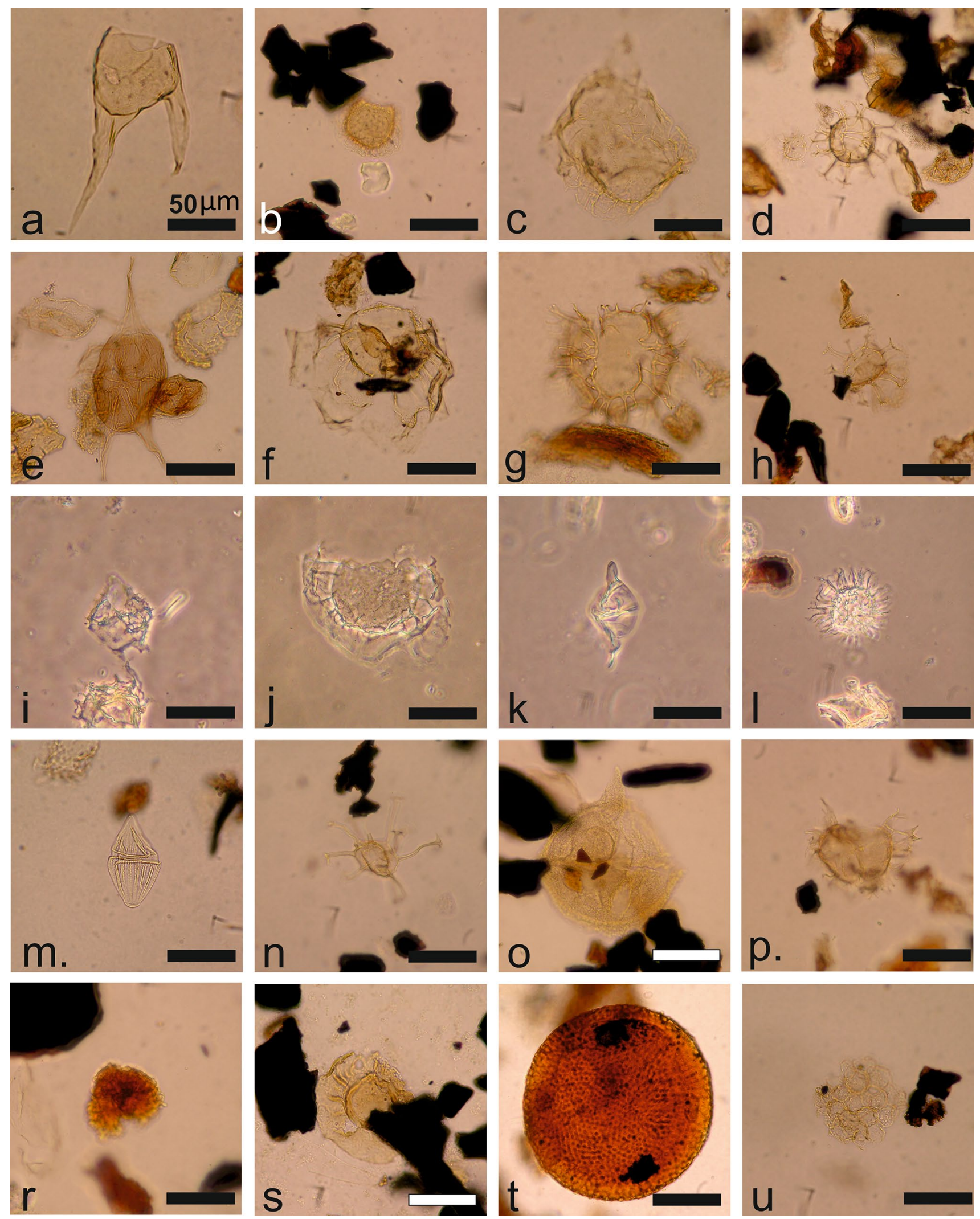
4Fig. 11 Photographs of the selected taxa of dinoflagellate cyst and other algae from studied samples. Scale bar of $50 \mu \mathrm{m}$ valid for all photographs. a Odontochitina operculata (Wetzel, 1933) Deflandre and Cookson, 1955, Pińczów. b Membranilarnacia sp Eisenack, 1963, Pińczów. c Spongodinium delitiense (Ehrenberg, 1838) Deflandre, 1936, Pełczyska 1/1. d Spiniferites ramosus (Ehrenberg, 1838) Mantell, 1854, Pełczyska 1/18. e Cerodinium diebelii Alberti, 1959) Lentin and Williams, 1987, Pełczyska 1/18. f Riculacysta amplexa Kirsch, 1991, Brynica Mokra. g Areoligera senonensis Lejeune-Carpentier, 1938, Michałów. h Hystrichosphaeridium tubiferum (Ehrenberg, 1838) Deflandre, 1937, Pińczów. i Spinidinium eggeri Kirsch, 1991, Pełczyska 1/1. j Glaphyrocysta semitecta (Bujak, 1980) Lentin and Williams, 1981, Brynica Mokra. k Biconidinium reductum (May, 1980,) Kirsch, 1991, Pińczów. I Heterosphaeridium sp Cookson and Eisenack, 1968, Kozubów. m Dinogymnium acuminatum Evitt et al., 1967, Pełczyska 1/18. n Oligosphaeridium complex (White, 1842) Davey and Williams, 1966, Michałów. o Apteodinium delicatum (Davey, 1975) Schrank, 1987, Pińczów. p Palynodinium grallator Gocht, 1970, Pełczyska 1/1. q Botrycoccus sp., Pełczyska 1/1. r Pterospermella sp., Pińczów. s Tasmanites sp., Pińczów. t Palambages sp., Pełczyska, 1/1

Cretaceous carbonate-siliciclastic rocks. The models of organic matter distribution which originated from clastic sedimentary systems (Tyson and Follows 2000; Roncaglia and Kuijpers 2006) could not be directly applied to carbonate sedimentary systems (Courtinat and Malartre 2003; Goetz et al. 2008). The dynamic nature of sedimentary basins and carbonate sediments influenced by siliciclastic deposits have to be carefully considered are especially important for creating meaningful paleogeographic reconstructions. According to Zeller et al. (2015), a mixing of carbonate production and siliciclastic input causes variable sedimentation conditions and a high degree of lateral and vertical facies heterogeneity. Generally, carbonate facies development is triggered by the requirements of the carbonate-secreting biota, which are controlled by temperature, salinity, sealevel change, input of siliciclastic sediments, and nutrients (Sanders and Höfling 2000). It seems that the sedimentary conditions of the Late Cretaceous low-energy basin in the Miechów Synclinorium have been predominately driven by blooms of coccolithophores (Saavedra-Pellitero et al. 2014) as well as inputs of siliciclastic deposits of terrestrial origin. These conditions lead to restricted environments unaffected by high energetic sedimentary processes more characteristic for clastic deposits and classic carbonate ramp setting (Courtinat and Malartre 2003). Therefore, it seems that the aforementioned trends within sizes of opaque phytoclasts as well the diversity indexes for particulate organic matter are a reliable proxy of shoreline distance within the studied area. The application of these parameters combined with those from palynofacies and phytoplankton analyses allowed for reconstructions of proximal-distal palynofacies trends to be distinguished (Fig. 12) (Tyson and Follows 2000; Tyson 1993; Batten 1982; Goetz et al. 2008).
The first group of palynofacies characterized by high abundance of particulate organic matter is dominated by land-derived components with a predominance of opaque phytoclast pollen grains as well as large and intact cuticle particles, resin, and cortex. This, combined with a higher diversity of organic particles and maximum sizes of opaque phytoclast, indicates proximal conditions in the Wola Chroberska and Pełczyska sections. These sections are conspicuously enriched in AOM, indicating lagoonal conditions or vicinity of marshes, where AOM is well preserved (Rich 1989). Moreover, in Pełczyska, the occurrence of chlorococcale algae, represented by Botrycoccus sp. (Traverse 1988; Wetzel 1983) and Palambages sp. (Prauss 2000), confirms the influence of fresh water, at least occasionally. Botryococcus algae are widely used in palynological studies to determine fresh water environments (lacustrine, fluvial, lagoon, and deltaic) (e.g., Batten and Lister 1988; Guy-Ohlson and Norling 1988; Riding et al. 1991; Williams 1992). Subsequently, Botryococcus colonies may be transported by the rivers towards marine shelf facies (Combaz et al. 1977; Caratini et al. 1983; Guy-Ohlson 1986; Prauss 1989) and therefore often occur together with marine algae.

An increased occurrence of prasinophyte algae, represented by Tasmanites sp. and Pterospermella (Tappan 1980; Bernier and Courtinat 1979; Prauss 1989) with large intact cuticle tissues and needle-shaped phytoclasts, seems to confirm a close distance of these sites to the fluvio-deltaic or lagoonal environments, and probably local water stratification (Tyson 1984, 1993). This is further indicated by the apparent influx of terrestrial palynomorphs in the Kozubów and Michałów sections.

The first subgroup within the second group of palynofacies, predominated by opaque particles with moderate content of translucent phytoclast and sporomorphs indicates intermediate palynofacies. This is further supported by the moderate index diversity and medium value of opaque phytoclast sizes. The absence of intermediate palynofacies in the T. radiosus Zone is the result of lacking the outcrops due to the extensive cover of the Maastrichtian rocks by younger deposits. The conspicuous enrichment of bissacate pollen grains in the Dziewięcioły section, located in intermediate palynofacies, is probably due to bypass processes (Mildenhall 2003) generated by wind transport from the conifer-rich area of Pełczyska site located next to the postulated land area.

The second subgroup of the second palynofacies group, composed almost solely of phytoclasts with high content of opaque particles, is characterized by the lowest diversity index and smallest size values of opaque phytoclast, and indicates the distal palynofacies of the studied sections.

The declining tendencies of marine palynomorphs from the proximal, through the intermediate, towards the distal part of the shelf are probably driven by local nutrient 
Fig. 12 Palynofacies interpretation of studied area during Maastrichtian time

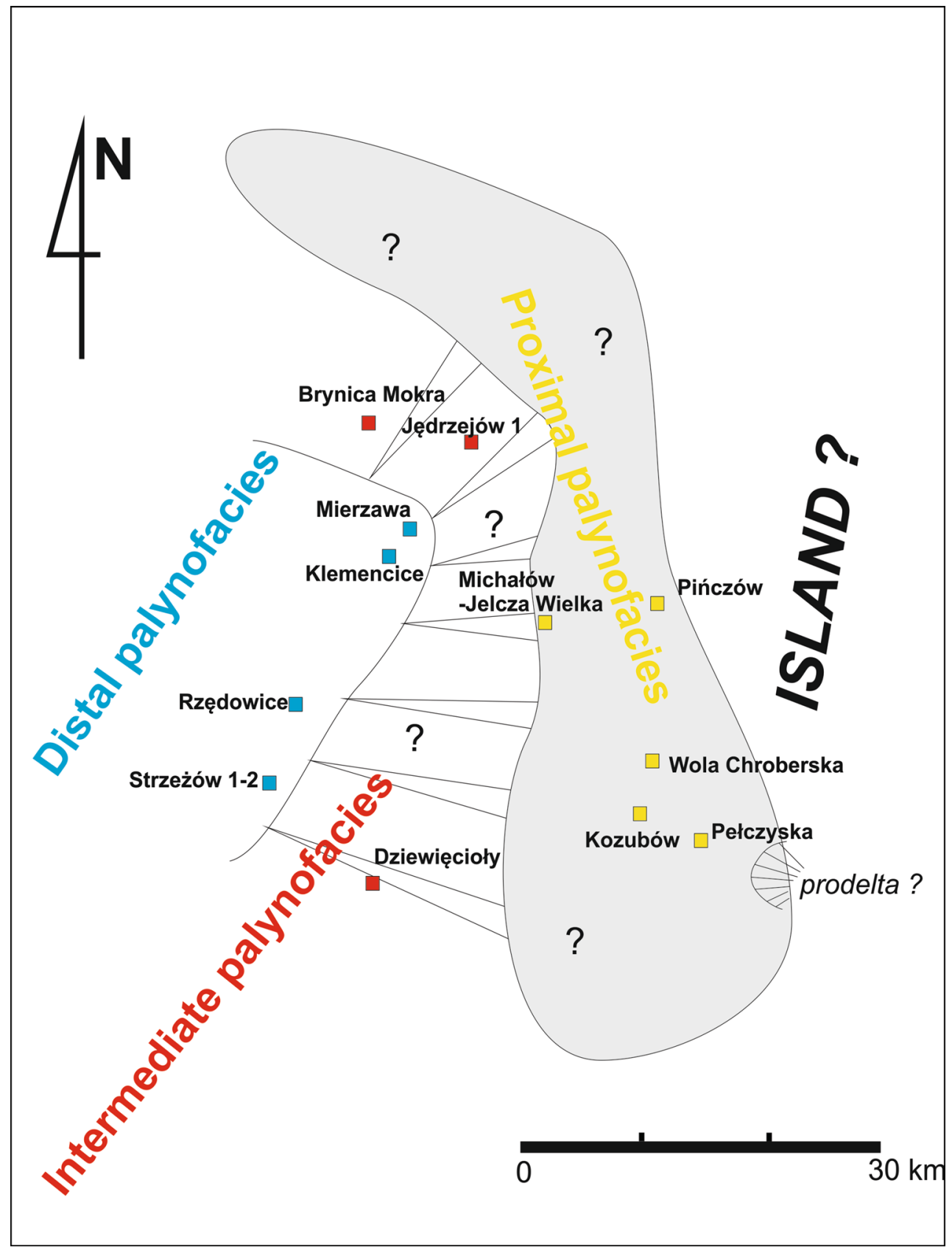

circulation in the basin. Dinoflagellates produce fossil cysts during periods of unstable conditions in shallow-water environments along continental margins and around oceanic archipelagos (Wall et al. 1977). In normal conditions, the abundance of dinoflagellate cysts is in inverse proportion to the content of terrestrial palynomorphs. However, they can predominate in shelf areas devoid of active fluvio-deltaic influences, in areas poorly covered by vegetation, and in areas of enhanced primary productivity (Tyson 1993). Increased productivity is usually the effect of upwelling currents generated by wind, or nutrient influx by terrestrial runoff (Davey 1970; Davey and Rogers 1975; Hooghiemstra et al. 1986). It often results in an enrichment in peridinioid dinoflagellate cyst taxa (Wall et al. 1977; Bujak 1984). According to many authors (Downie et al. 1971; Davey 1970; Mutterlose and Harding 1987; Lister and Batten 1988), peridinioid-dominated assemblages are also indicative of nearshore lagoonal, estuarine, or brackish water environments (Pełczyska). Generally, dinoflagellate cyst diversity shows on offshore increase. However, reversed tendencies sometimes occur in estuarine environments (Wall et al. 1977; Morzadec-Kerfourn 1977; Tyler et al. 1982). Impoverished macrofauna assemblages observed by 

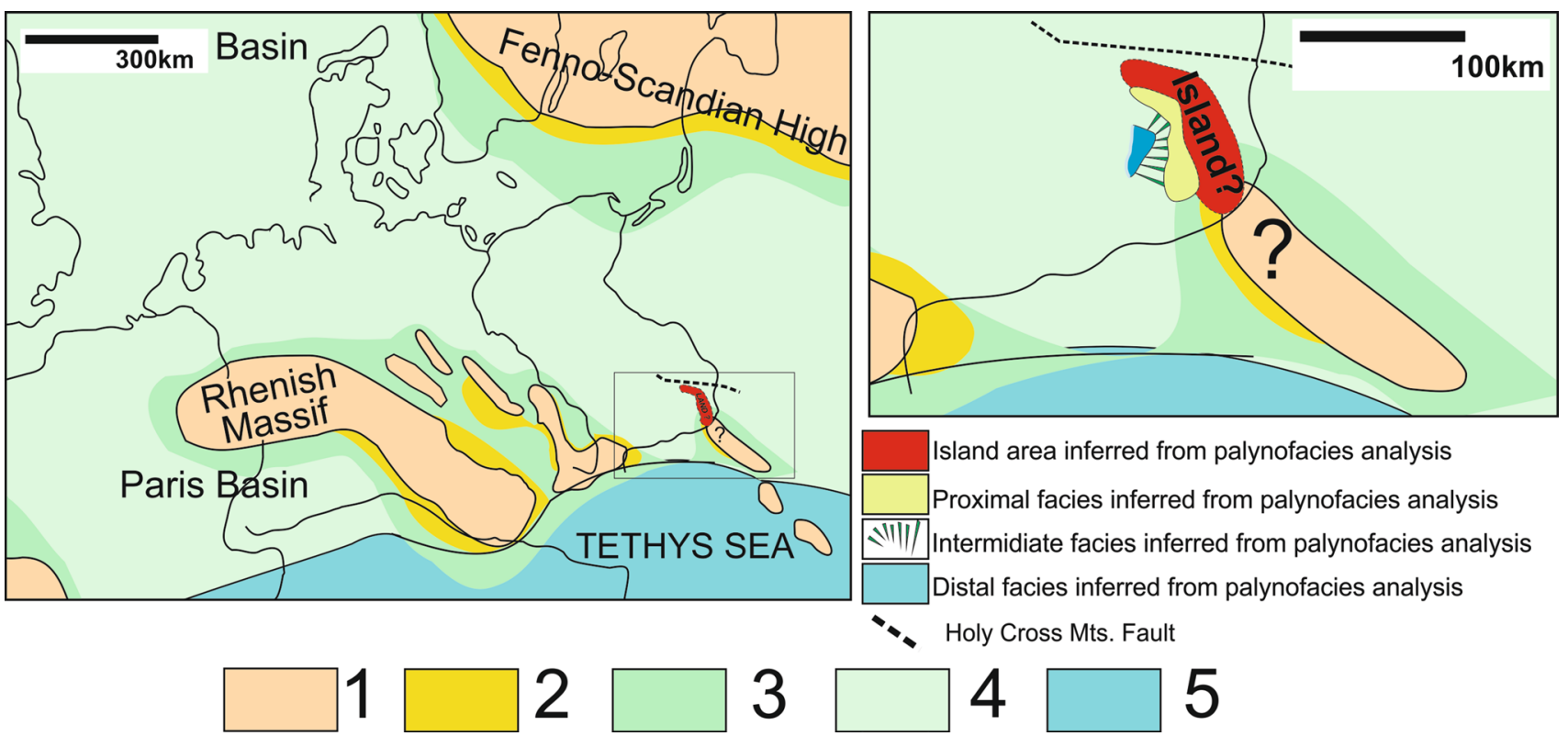

Fig. 13 Simplified Late Cretaceous (75 Ma) paleogeographic map (Naidin 1959; Kauffman 1973; Ziegler 1990; Philip et al. 2000; Świdrowska et al. 2008; Jurkowska et al. 2015 modified; Bojanowski et al. 2017) with regional paleogeographical data inferred from

Jurkowska (2016) also reflect offshore diminishing diversity and abundance in the Miechów Synclinorium.

The results presented here suggest the occurrence of an island area in close proximity of the sections belonging to the first group, i.e., the proximal palynofacies. The proximal part of this system is indicated by a high diversity of terrestrial organic matter, influence of fresh water input (Botrycoccus), high productivity probably controlled by terrestrial runoff, which results in high abundance of peridinioid dinoflagellate cysts and larger sizes of opaque phytoclasts. Towards the distal part of the shelf, the number of terrestrial-derived particles and dinoflagellates declines, and the size of wood particles and the diversity indexes are reduced. The distal facies are practically solely represented by opaque phytoclasts assemblages of rounded shapes and small sizes. The low number of dinoflagellate cysts in this part of the system is explained by local trophic conditions.

The island, which was probably connected with the Kukernitz Island (Fig. 13) was located close to the Danish-Polish Trough (present day Mid-Polish Anticlinorium). Generally, two divergent opinions of the time of inversion of the Danish-Polish Trough have been established. Dadlez et al. (1997) and Leszczyński (2012) presented the idea of a multiphase inversion, which may have started during Santonian-Campanian and reactivated older synsedimentary structures. The key data for this interpretation is based on lithofacies pattern and geometry of the Upper Cretaceous succession and thickness analysis. Kutek and Głazek (1972), Świdrowska and Hakenberg (1999), Świdrowska et al. (2008), and Jurkowska palynofacies analysis. 1 areas of non-deposition, 2 deltaic, coastal and shallow-marine siliciclastic facies, 3 near-shore facies, 4 shallowmarine facies, 5 deeper-marine facies

(2016) presented data which indicate that the inversion could not have started before the Maastrichtian. This is based on the increasing thickness of the whole Upper Cretaceous succession in the direction of the Holly Cross Mountains (Kutek and Głazek 1972; Heller and Moryc 1984; Świdrowska and Hakenberg 1999; Świdrowska et al. 2008; Jurkowska 2016). Świdrowska and Hakenberg (1999) also presented lithofacies data of Upper Cretaceous deposits, indicating increasing water depths towards the Holy Cross Mountains. Recently, based on detailed stratigraphy, a more complicated model of inversion has been discussed (Walaszczyk and Remin 2015; Jurkowska 2016). New high-resolution seismic data (Krzywiec 2000; Krzywiec et al. 2009) also indicate a more complicated model in which the individual parts of the Danish-Polish Trough have been inverted at different times.

The data presented in this paper indicate that during the early Late Maastrichtian, the sea was still present in the Miechów Synclinorium, and an uplifted area of the Holly Cross Mountains part of the Danish-Polish Trough was emerged and was providing the terrigenous material to the southeastern areas.

\section{Conclusions}

The palynological study combined with a palynofacies analysis supported by size analysis of opaque phytoclasts and diversity indexes for particulate organic matter in well stratigraphically constrained monotonous Upper Cretaceous 
carbonate-siliciclastic sediments devoid of unequivocal sedimentological and paleontological data is a valuable tool in determining the depositional environments. Despite the monotonous lithology and the lack of macrofaunistic paleoenvironmental indicators, the distribution of sedimentary organic matter suggests the occurrence of proximal to distal shelf facies belts with a well-developed intermediate facies zone. The size analysis of opaque phytoclasts indicates a close distance of the studied area from the shore. This is also confirmed by the increased quantity of chlorococcale algae represented by Botrycoccus sp. and Palambages sp. and the increase number of heterotrophic Peridinioid species and foraminifera test linings in proximal samples. The presented data indicate that during the Maastrichtian an uplifted area existed in the Holy Cross part of the DanishPolish Trough. The youngest Upper Cretaceous rocks of the Miechów Synclinorium, for the first time described in the present paper, indicate that the sea was still present during the early Late Maastrichtian.

Acknowledgements This work was supported by AGH statutory grants from the AGH University of Science and Technology (DS: 11.11.140.626) and statutory grants of Institute of Geology, Warsaw University. We are very grateful to Prof. Marcin Machalski (Polish Academy of Sciences), Dr. Axel Munnecke (Friedrich-Alexander Universität Erlangen-Nürnberg) and anonymous reviewer for constructive comments on the earlier version of the manuscript. The authors are greatly indebted to Marta Szczepanik and Kyle Freeman for linguistics corrections.

Open Access This article is distributed under the terms of the Creative Commons Attribution 4.0 International License (http://creativecommons.org/licenses/by/4.0/), which permits unrestricted use, distribution, and reproduction in any medium, provided you give appropriate credit to the original author(s) and the source, provide a link to the Creative Commons license, and indicate if changes were made.

\section{References}

Batten DJ (1982) Palynofacies, palaeoenvironments, and petroleum. J Micropalaeontol 1:107-114

Batten DJ, Lister LK (1988) Evidence of freshwater dinoflagellates and other algae in the English Wealden (Early Cretaceous). Cretac Res 9:171-179

Bernier P, Courtinat B (1979) Le microplankton (Leiosphaeridia) et la matiere organique des calcaires d'arrier-recif du Kimmeridgien Superieur dans le Jura Meridional. Systematique, conditions de genese et d'environment. Documents du Laboratoire Gologique, Faculte des Sciences Lyon 75:95-117

Bojanowski MJ, Dubicka Z, Minoletti F, Olszewska-Nejbert D, Surowski M (2017) Stable C and O isotopic study of the Campanian chalk from the Mielnik section (eastern Poland): signals from bulk rock, belemnites, benthic foraminifera, nannofossils and microcrystalline cements. Palaeogeogr Palaeoclimatol Palaeoecol 465:193-211. doi:10.1016/j.palaeo.2016.10.032

Bujak JP (1984) Cenozoic dinoflagellate cysts and acritarchs from the Bering Sea and northern Pacific, DSDP Leg 19. Micropaleontology 30:180-212
Caratini C, Bellet J, Tissot C (1983) Les palynofacies: representation graphique, interet de leur etude pour les reconstitutions paleogeographiques. Geochimie Organique des Sediments Marins d'ORGON a MISEDOR. Editions du Centre National de la Recherche Scientifique, Paris 327-351

Cieśliński S, Milacović B (1962) Kręgowce i flora kredowa z obrzeżenia Gór Świętokrzyskich. Biuletyn Instytutu Geologicznego 174:245-258

Combaz A, Bellet J, Poulain D, Caratini C, Tissot C (1977) Etude microscopique de la matiere organique de sediments Quaternaires de mer de Norvege, in Geochimie Organique des Sediments Marins Profonds, ORGON I: Mer de Norvege, Editions du Centre National de la Recherche Scientifique, Paris 139-175

Courtinat B, Malartre F (2003) Palynofacies variations in a carbonate ramp system environment (Upper Muschelkalk, NE France). Bulletin de la Société Géologique de France 174(6):595-601

Dadlez R, Jóźwiak W, Młynarski S (1997) Subsidence and inversion in the western part of Polish basin-data from seismic velocities. Geol Q 41:197-208

Dadlez R, Marek S, Pokorski J (2000) Geological map of Poland; scale: 1:1000000. Warszawa, Państwowy Instytut Geologiczny

Davey RJ (1970) Non-calcareous microplankton from the Cenomanian of England, northern France and North America, part II. Bull Br Mus (Nat Hist) Geol 18(8):333-397

Davey RJ, Rogers J (1975) Palynomorph distribution in Recent offshore sediments along two traverses off South West Africa. Mar Geol 18:213-225

Degens ET, Mopper K (1976) Factors controlling the distribution and early diagenesis of organic material in marine sediments. In: Riley JP, Chester R (eds) Chemical oceanography. Academic, Dordrecht, pp 59-113

Downie C, Hussain MA, Williams GL (1971) Dinoflagellate cysts and acritarch associations in the Paleogene of southeast England. Geosci Man 3:29-35

Dubicka Z, Peryt D, Szuszkiewicz M (2014) Foraminiferal evidence for paleogeographic and paleoenvironmental changes across the Coniacian-Santonian boundary in western Ukraine. Palaeogeogr Palaeoclimatol Palaeoecol 401:43-56

Gierliński G (2015) New dinosaur footprints from the Upper Cretaceous of Poland in the light of paleogeographic context. Ichnos $22: 220-226$

Goetz AE, Feist-Burkhardt S, Ruckwied K (2008) Palynofacies and sea-level changes in the Upper Cretaceous of the Vocontian Basin, southeast France. Cretac Res 29:1047-1057

Guy-Ohlson D (1986) Jurassic Palynology of the Vilhelmstfiilt Bore No. 1, Scania, Sweden. Toarcian Aalenian, Section of Palaeobotany, Swedish Museum of Natural History, Stockholm

Guy-Ohlson D, Norling E (1988) Upper Jurassic litho- and biostratigraphy of NW Scania, Sweden. Sveriges Geologiska Undersokning, Uppsala

Halamski AT (2013) Latest Cretaceous leaf floras from southern Poland and western Ukraine. Acta Paleontologica Polonica 58:407-443

Hammer Ø, Harper D, Ryan PD (2001) Past: paleontological statistics software package for education and data analysis. Palaeontol Electron 4:4-9

Heller I, Moryc W (1984) Stratygrafia utworów kredy górnej Przedgórza Karpat. Biuletyn Instytutu Geologicznego 24:63-108

Hooghiemstra H, Agwu COC, Beug HJ (1986) Pollen and spore distribution in Recent marine sediments: a record of NW-African seasonal wind patterns and vegetation belts. 'Meteor' Forschungsergebnisse C40:87-135

Jaskowiak-Schoeneichowa M, Krassowska A (1988) Paleothickness, lithofacies and paleotectonics of the epicontinental Upper Cretaceous of Poland. Kwartalnik Geologiczny 32:177-198 
Jurkowska A (2016) Inoceramid stratigraphy and depositional architecture of the Campanian and Maastrichtian of the Miechów Synclinorium (southern Poland). Acta Geol Pol 66:59-84

Jurkowska A, Świerczewska-Gładysz E, Dubicka Z, Olszewska-Nejbert D (2015) Porosphaera globularis (Phillips, 1829) (Porifera, Calcarea) in the Campanian (Upper Cretaceous) of extra-Carpathian Poland. Acta Geol Pol 65:121-139

Fugger E, Kastner, C (1885) Naturwissenschaftliche Studien und Beobachtungen aus und über Salzburg. H. Kerber:77-80

Kauffman EG (1973) Cretaceous Bivalvia. In: Hallam AH (ed) Atlas of palaeobiogeography. Elsevier, Amsterdam, p 353-386

Krzywiec P (2000) On mechanism of the mid-polish trough inversion. Pol Geol Inst Bull 393:135-166

Krzywiec P (2006) Structural inversion of the Pomeranian and Kuiavian segments of the mid-polish trough-lateral variations in timing and structural style. Geol Q 50:151-168

Krzywiec P, Gutowski J, Walaszczyk I, Wrobel G, Wybraniec S (2009) Tectonostratigraphic model of the Late Cretaceous inversion along the Nowe Miasto-Zawichost Fault Zone, SE Mid-Polish Trough. Geol Q 53:27-48

Kutek J (1996) Obszar Niecki Nidziańskiej jako część polskiego permsko-mezozoicznego basenu ryftowego. Zagadnienie geologii Niecki Nidziańskiej. Prace geografii WSP w Kielcach 1:51-68

Kutek J, Głazek J (1972) The Holly Cross area, central Poland in the Alpine cycle. Acta Geol Pol 22:603-653

Leszczyński K (2012) The internal geometry and lithofacies pattern of the Upper Cretaceous-Danian sequence in the Polish Lowlands. Geol Q 56:363-386

Lister JK, Batten DJ (1988) Stratigraphic and palaeo-environmental distribution of Early Cretaceous dinoflagellate cysts in the Hurlands Farm Borehole, West Sussex, England. Palaeontographica B210:9-89

Marcinowski R (1974) The transgressive Cretaceous (Upper Albian through Turonian) deposits of the Polish Jura Chain. Acta Geol Pol 24:117-217

Meek FB (1876) A report on the invertebrate Cretaceous and Tertiary fossils of the Upper Missouri country. U. S. Geol Survey Territories (Hayden) 9:1-629

Mildenhall DC (2003) Deep-sea record of Pliocene and Pleistocene terrestrial palynomorphs from offshore eastern New Zealand (ODP Site 1123, Leg 181). NZ J Geol Geophys 46:343-361

Morton SG (1834) Synopsis of the organic remains of the Cretaceous group of the United States. Illustrated by nineteen plates. To which is added an appendix, containing a tabular view of the Tertiary fossils hitherto discovered in North America. Philadelphia, Key and Biddle

Morzadec-Kerfourn MT (1977) Les Kystes de dinoflagelles dans les sediments Recents le long des Cotes Bretonnes. Revue de Micropaleontologie 20:157-166

Müller J (1959) Palynology of Recent Orinoco Delta and shelf sediments: reports of the Orinoco Shelf expedition. Micropaleontology $5: 1-2$

Mutterlose J, Harding I (1987) Phytoplankton from the anoxic sediments of the Barremian (Lower Cretaceous) of North-West Germany. Abhandlungen Geologischen Bundesanstalt, Wien 39:177-215

Naidin DP (1959) On the paleogeography of Russian Platform during the Upper Cretaceous epoch. Stockholm Contrib Geol 3:127-138

Pasternak SI (1959) Biostratygrafiya kreydovykh vidkladiv VolynoPodilskoi plyty. Vydavnytstvo Akademii Nauk Ukrainskoi RSR, Kiev, pp 3-98

Pasternak SI, Senkovskyi YM, Gavrylyshyn VI (1987) Volyno-Podillya u kreydovomu periodi. Naukova Dumka, Kiev, pp 3-258

Peryt D, Dubicka Z (2009) Stop 3. Paleoenvironmental changes in the Early Maastrichtian of the Nida Trough (Southern Poland): foraminiferal evidence. In: Peryt D, Kamiński MA (eds), 7th Micropaleontological Workshop. Abstract and Excursion Guide, pp 101-108

Philip J, Floquet M, Platel JP, Bergerat F, Sandulescu M, Baraboshkin E, Amon E, Poisson A, Guiraud R, Vaslet D, Le Nindrey Y, Ziegler M, Bouziz S, Guezou JC, Lepvrier C (2000) Early Campanian (83-80 Ma). In: Dercourt J, Gaetani M, Vrielynck B (eds), Atlas Peri-Tethys, Paleogeographical Maps: CCGM/CGMW Paris, Map 15

Pożaryski W (1962) Atlas Geologiczny Polski-zagadnienia stratygraficzno facjalne. Instytut Geologiczny, Warszawa

Pożaryski A (1977) Early Alpine (Laramide) epoch in the platform development east of the fore-Sudetic and Silesian-Cracovian monoclines. In: Pożaryski W (ed), Geology of Poland, Warsaw, p 351-413

Pożaryski W, Brochwicz-Lewiński W, Brodowicz Z, JaskowiakSzoenejch M, Milewicz J, Sawicki L, Uberna T (1979) Geological map of Poland and adjoining countries, without Cenozoic formations (without Quaternary in the Carpathians). Warszawa, Wydawnictwa Geologiczne

Prauss M (1989) Dinozysten-Stratigraphie und Palynofazies im Oberen Lias und Dogger von NW-Deutschland. Palaeontographica Abteilung B 214:1-124

Prauss M (2000) The oceanographic and climatic interpretation of marine palynomorph phytoplankton distribution from Mesozoic, Cenozoic and Recent sections. Göttinger Arbeiten zur Geologie und Paläontologie 76:1-235

Remin Z, Marshall J (2016) Changes in paleo-circulation and the distribution of ammonite faunas at the Coniacian-Santonian transition in the central Poland and western Ukraine. Acta Geol Pol 66:107-124

Rich FJ (1989) A review of the taphonomy of plant remains in lacustrine sediments. Rev Palaeobot Palynol 58:33-46

Riding JB, Walton W, Shaw D (1991) Toarcian to Bathonian (Jurassic) palynology of the Inner Hebrides, northwest Scotland. Palynology 15:115-180

Roncaglia L, Kuijpers A (2006) Revision of the palynofacies model of Tyson (1993) based on recent high-latitude sediments from the North Atlantic. Facies 52:19-39

Rutkowski J (1960) O utworach piaszczystych w mastrychcie okolic Krakowa. Rocz Pol Towarz Geol 30:289-303

Rutkowski J (1965) Senonian in the area of Miechów, southern Poland. Rocz Pol Towarz Geol 35:3-53

Saavedra-Pellitero M, Baumann KL, Flores JA, Gersonde R (2014) Biogeographic distribution of living coccolithophores in the Pacific sector of the Southern Ocean. Mar Micropaleontol 109:1-20

Samsonowicz J (1925) Szkic geologiczny okolic Rachowa nad Wisłą oraz transgresje albu i cenomanu w bruździe północnoeuropejskiej. Sprawozdania Polskiego Instytutu Geologicznego 3:45-98

Sanders D, Höfling R (2000) Carbonate deposition in mixed siliciclastic-carbonate environments on top of an orogenic wedge (Late Cretaceous, Northern Calcareous Alps, Austria). Sed Geol 137:127-146

Sornay J (1973) Sur les inocerames du Maestrichtien de Madagascar et sur une espece de la Craie a Baculites du NW de la France. Annales de Paleontologie (Invertebres) 59:83-93

Świdrowska J, Hakenberg M (1999) Subsydencja i początki inwersji bruzdy śródpolskiej na podstawie analizy map miąższości i litofacji osadów górnokredowych. Przegląd Geologiczny 47:61-68

Świdrowska J, Hakenberg M, Poluthović B, Seghedi A, Višnakov I (2008) Evolution of the Mesozoic basins on the southwestern edge of the East European Craton (Poland, Ukraine, Moldova, Romania). Studia Geologica Polonica 130:3-130 
Tappan H (1980) The paleobiology of plant protists. Freeman and Company, San Francisco

Traverse A (1988) Paleopalynology. Unwin Hyman, Boston

Tyler MA, Coats DW, Anderson DM (1982) Encystment in a dynamic environment: deposition of dinoflagellate cysts by a frontal convergence. Mar Ecol Prog Ser 7:163-178

Tyson RV (1984) Palynofacies investigation of Callovian (Middle Jurassic) sediments from DSDP Site 534, Blake-Bahama Basin, western Central Atlantic. Mar Pet Geol 1:3-13

Tyson RV (1993) Palynofacies analysis. In: Jenkins DG (ed) Applied Micropaleontology. Kluwer Academic Publishers, Amsterdam, pp 153-191

Tyson RV (1995) Sedimentary Organic Matter. Organic facies and palynofacies. Chapman and Hall, London

Tyson RV, Follows B (2000) Palynofacies prediction of distance from sediment source: a case study from the Upper Cretaceous of the Pyrenees. Geology 28:569-572

Von Hagenow F (1842) Monographie der Rügenschen Kreideversteinerungen. III. Abteilung: mollusken. Neues Jahrbuch für Mineralogie, Geognosie, Geologie und Petrefaktenkunde 1842:528-575

Walaszczyk I (1992) Turonian through Santonian deposits of the Central Polish Uplands; their facies development, inoceramid paleontology and stratigraphy. Acta Geologica Polonica 42:1-122

Walaszczyk I, Remin Z (2015) Kreda obrzeżenia Gór Świętokrzyskich. In: Skompski S, Mizerski W (eds) Ekstensja i Inwersja Powaryscyjskich Basenów Sedymentacyjnych. LXXXVI Zjazd Naukowy Polskiego Towarzystwa Geologicznego, Gdańsk, pp 41-50

Walaszczyk I, Cobban WA, Harries PJ (2001) Inoceramids and inoceramid biostratigraphy of the Campanian and Maastrichtian of the United States Western Interior Basin. Rev Paléobiol 20:117-234

Walaszczyk I, Kennedy WJ, Klinger HC (2009) Cretaceous faunas from Zululand and Natal, South Africa. Systematic palaeontology and stratigraphical potential of the Upper Campanian-Maastrichtian Inoceramidae (Bivalvia). Afr Nat Hist 5:49-132

Walaszczyk I, Jagt J, Keutgen N (2010) The "youngest" true inoceramids from the Vijlen Member (Gulpen Formation) in northeast Belgium and the Aachaen area (Germany). Netherlands J Geosci 89:147-167
Walaszczyk I, Dubicka Z, Olszewska-Nejbert D, Remin Z (2016) Integrated biostratigraphy of the Santonian trough Maastrichtian (Upper Cretaceous) of extra-Carpathian Poland. Acta Geol Pol 66(3):312-350

Wall D, Dale B, Lohmann GP, Smith WK (1977) The environment and climatic distribution of dinoflagellate cysts in modern marine sediments from regions in the North and South Atlantic Oceans and adjacent seas. Mar Micropalaeontol 2:121-200

Wetzel RG (1983) Limnology. Saunders College Publishing, Philadelphia

Whitfield RP (1877) Preliminary report on the paleontology of the Black Hills containing descriptions of new species of fossils of Potsdam, Jurassic and Cretaceous Formation of Black Hills of Dakota. United States Geographical and Geological Survey of the Rocky Mountain Region, Washington, p 49

Williams GL (1992) Palynology as a palaeoenvironmental indicator in the Brent Group, northern North Sea. In: Morton AC, Haszeldine RS, Giles MR, Brown S (eds) Geology of the Brent Group. Geological Society of London Special Publication, London, pp 203-212

Żelaźniewicz A (2008) Tectonic subdivision of Poland-state of the art and attempt to revision. Przegląd Geologiczny 56:887-894

Żelaźniewicz A, Aleksandrowski P, Buła Z, Karnkowski PH, Konon A, Oszczypko N, Ślączka A, Żaba J, Żytko K (2011) Regionalizacja tektoniczna Polski. Komitet Nauk Geologicznych PAN, Wrocław, pp 1-60

Zeller M, Verwer K, Eberli GP, Massaferro JL, Schwarz E, Spalletti L (2015) Depositional controls on mixed carbonate-siliciclastic cycles and sequences on gently inclined shelf profiles. Sedimentology 62:2009-2037

Ziegler PA (1990) Geological Atlas of Western and Central Europe, 2nd edn. Shell Internationale Petroleum Maatschappij B.V.; Mijdrecht, Mijdrecht

Zobaa MK, El Beialy SY, Taha A, Oboh-Ikuenobe FE (2015) Improved graphical representation of sedimentary organic matter as paleoenvironmental parameters. Geol Soc Am Abstr Prog 47(7):365 